\title{
Eco-Urban Approach for Foca Peninsula (Izmir, Turkey)
}

\author{
Nurhan KOÇAN ${ }^{1}$, Gökhan BALIK ${ }^{2 *}$ \\ ${ }^{1}$ Bartın University, Faculty of Forestry, Department of Landscape Architecture, Bartın, Turkey \\ ${ }^{2}$ Trakya University, Faculty of Architecture, Department of Landscape Architecture, Edirne, Turkey
}

\begin{abstract}
Foca Peninsula is an ecologically and culturally rich region, characterizing the Mediterranean landscape with its rural, urban, coastal areas and islands. It contains forest landscapes, archeological heritages and historical urban areas. This paper examines the potentials of the peninsula as a whole, for the suitability of eco-urban concept. The objectives of the eco-urban approach are: providing clean and efficient energy by using renewable energy resources, improving local economic development by encouraging agricultural activities, preventing emigration by holding the labor force inside the peninsula, increasing regional collaboration, creating a physically and culturally rich center. Considering the concept, this paper aims to create an 'eco-urban' that respects the natural system, provides sustainable and modern conditions. This research evaluates Foca Peninsula in the scales of $1 / 25.000,1 / 10.000$ and 1/5.000. In these scales, the paper reveals the visions, strategies, plans and designs. As of region analysis, transportation; demography; visual, survey and SWOT analyses and questionnaire with 10 questions, filled by 100 people were performed. As a result, this paper discusses the landscape planning and design outputs according to the eco-urban approach.
\end{abstract}

Keywords: Eco-urban, Landscape planning and design, Foca Peninsula, Planning studio, Design studio.

\section{Foça Yarımadası'nda Eco-Urban Yaklaşımının Uygulanması (İzmir)}

\section{Öz}

Foca Yarımadası; kırsal, kentsel, kıyı alanları ile adaları bünyesinde barındırdığı doğal ve kültürel potansiyeli, arkeolojik zenginlikleri, tarihi kentsel dokusu ve turizm çeşitliliği ile Akdeniz peyzajını karakterize eden önemli bir bölgedir. Foca Yarımadası orman peyzajı, arkeolojik miras, tarihi kent yerleşimi gibi önemli alanlar içerir. Çalışmada Foca Yarımadası ekokent yaklaşımı dahilinde yarımadanın potansiyelleri kapsamında incelenmiştir. Ekokent yaklaşımının amacı yenilenebilir enerji kaynaklarını kullanarak temiz ve etkin enerji sağlamak, tarımı teşvik ederek ekonomik gelişme ve yerel kalkınmayı geliştirmek, insan gücünü yarımada içinde tutarak dışa göçleri önlemek, bölgesel işbirliğini arttırmak ve en önemlisi de ekolojik yaklaşımla fiziksel ve kültürel çehresi zengin bir yaşam merkezi oluşturabilmektir. Çalışmada doğal süreçlere saygı duyan, sürdürülebilir ve modern koşullar sağlayan 'bir eko-kent' oluşturmak amaçlanmaktadır. Foca Yarımadası, 1/25.000, 1/10.000 ve 1/5.000 ölçeklerinde ele alınmıştır. Bu kapsamda; vizyon, stratejiler, plan ve tasarımlar geliştirilmiştir. Bölge analizi olarak ulaşım, demografi, meteoroloji, SWOT ve görsel analiz yapılmış, 10 sorudan oluşan bir anket 100 kişiye uygulanmıştır. Sonuçta peyzaj planlama ve tasarımları sunulmuş ve öneriler geliştirilerek konsept bağlamında tartışılmıştır.

Anahtar Kelimeler: Foca Yarımadası, Eko-kent, Peyzaj planlama ve tasarım, Planlama stüdyosu, Tasarım stüdyosu. 


\section{Introduction}

Mankind uses natural areas and consumes natural resources beyond measure. Because of this, the ecological and environmental problems became apparent in the 20th century. Since then, the decision makers realized that the humans must live in harmony with nature to secure their future. Besides, they began to understand the importance of the ecological approach.

The ecological approach includes actions and measures that cover protection and improvement of nature and preventing any harmful effects, damage or destruction of life and living creatures continuously. Natural areas have an important function for providing food, clean air, and adequate water, which are required for humanity not only today but also in the future. Sustainable use of natural areas with ecological approach; ensures the balance between long term use and protection of natural resources by examining the effects of human and other species behavior on environment; solves environmental problems, provides better living conditions and comfort.

Necessary works require energy and time management to prevent the consumption of natural resources in an unconscious way. Plans and designs are made to ensure the sustainable use of natural areas and sources regarding cultural, economic, social, and ecological structures and economic benefits are increased to maximize the level. In this way, natural areas and resources will contribute to the ecological and economic value and provide recognition of the local services in the world.

Foca Peninsula characterizes archeological heritages, historical urban texture. The main purposes of the ecourban approach are providing clean and efficient energy by using renewable energy resources, improving local economic development by encouraging agricultural activities, preventing emigration by holding the labor force inside the peninsula, increasing regional collaboration, sharing and connectivity, and most importantly, creating a physically and culturally rich life center .

Emerging as the result of research and efforts, eco-urban is a series of urban planning, design and implication that covers the interaction and communication of people, urban and environment. The principles of eco-urban approach are decreasing the pressures of urban on nature, using renewable energy resources, producing wastes at minimum levels, using recycled materials, and minimizing ecological footsteps.

The objectives of the study are:

- To build a living urban by gaining support of locals through populism principle,

- To identify and to trigger peninsula's natural, cultural, environmental, historical potentials,

- To support local development and cultural protection,

- $\quad$ To develop management.

\section{Materials and Methods}

Foca Peninsula is one of the 30 counties of Izmir Province, and it is 72 kilometers far from the city center. The acreage of Foca is $245 \mathrm{~km}^{2}$ and its coast length is $55 \mathrm{~km}$. Foca Peninsula, some part of it is located on Gediz water basin, is surrounded by Izmir-Canakkale highway on the east, Aliaga and Candarli Bay on the north, Aegean Sea on the west and İzmir Bay and Gediz Delta on the south (Kaplan, 1995). Foca is located on Saros / Erzurum 1st degree seismic belt. Across the bay there are Incir, Orak and Fener islands that make Foca a natural harbor. There are Hayirsiz Island and Metalik Island accross the Mersinaki Bay. The highest hills are Saphane Hill which has a height of 450 meters, Kartal (435 m.) and Kizildagi (352 m.) hills. The plains of Foca County are Ilipinar, Gencelli (Yeni Foca-Kozbeyli), Gerenkoy, Bagarasi and Yenibagarasi. On the border of the county, Kisla Stream which is an important branch of Gediz River flows (Çetin, 2002).

The history of Foca lies through 9th century B.C. by being one of the most important Ionian settlements. The structure of the ancient settlement belongs to the urban culture from the past. The urban center neighborhood and transportation network leads to the coast by perpendicular narrow streets (Cetin, 2002). The main sources of living are tourism, agriculture, stockbreeding, fishing, and small agricultural industries. The current population of Foca County is 33.227 .

The archeological, natural, urban and architectural values of Foca take place as a whole. Coastal regions between Yeni Foca and urban settlement of Foca are natural protected areas while major urban settlements are 
archeologically protected areas (Figure 1).
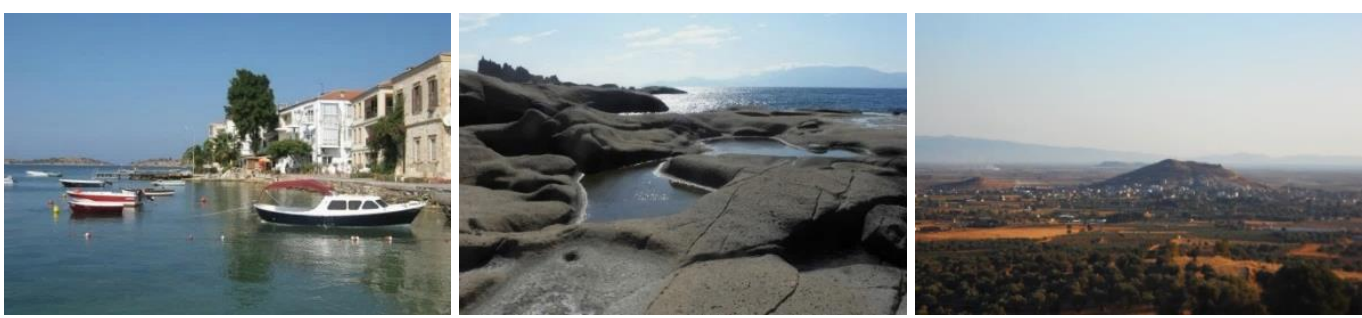

Figure 1. Foça Peninsula is characterized by the urban settlement (left), coast zones (center) and rural settlements (right).

Foca is a military territory. It was claimed as a special environment protection area in 1990 due to the natural and cultural potentials, tourism and recreational advantages, topographical-geomorphological structures and characteristics, existing habitat of extinction Mediterranean monk seals (Monachus monachus) (Kaboğlu, 2007).

In the study, transportation analysis, circulation analysis, demography analysis, meteorology analysis, SWOT analysis, visual analysis, and survey studies were completed but this paper only reveals the survey studies, visual analysis, and SWOT analysis due to page and word restrictions.

Foca Peninsula was evaluated in scales of 1/25.000, 1/10.000 and 1/5.000. Hence with the approach of ecourban as indigenous to peninsula, tangible and feasible visions, strategies, plans and designs were improved. In this process, plans and designs were performed which are integrated with each other. The future of Foca in the next 50 and 100 years were foreseen and planned (Figure 2).

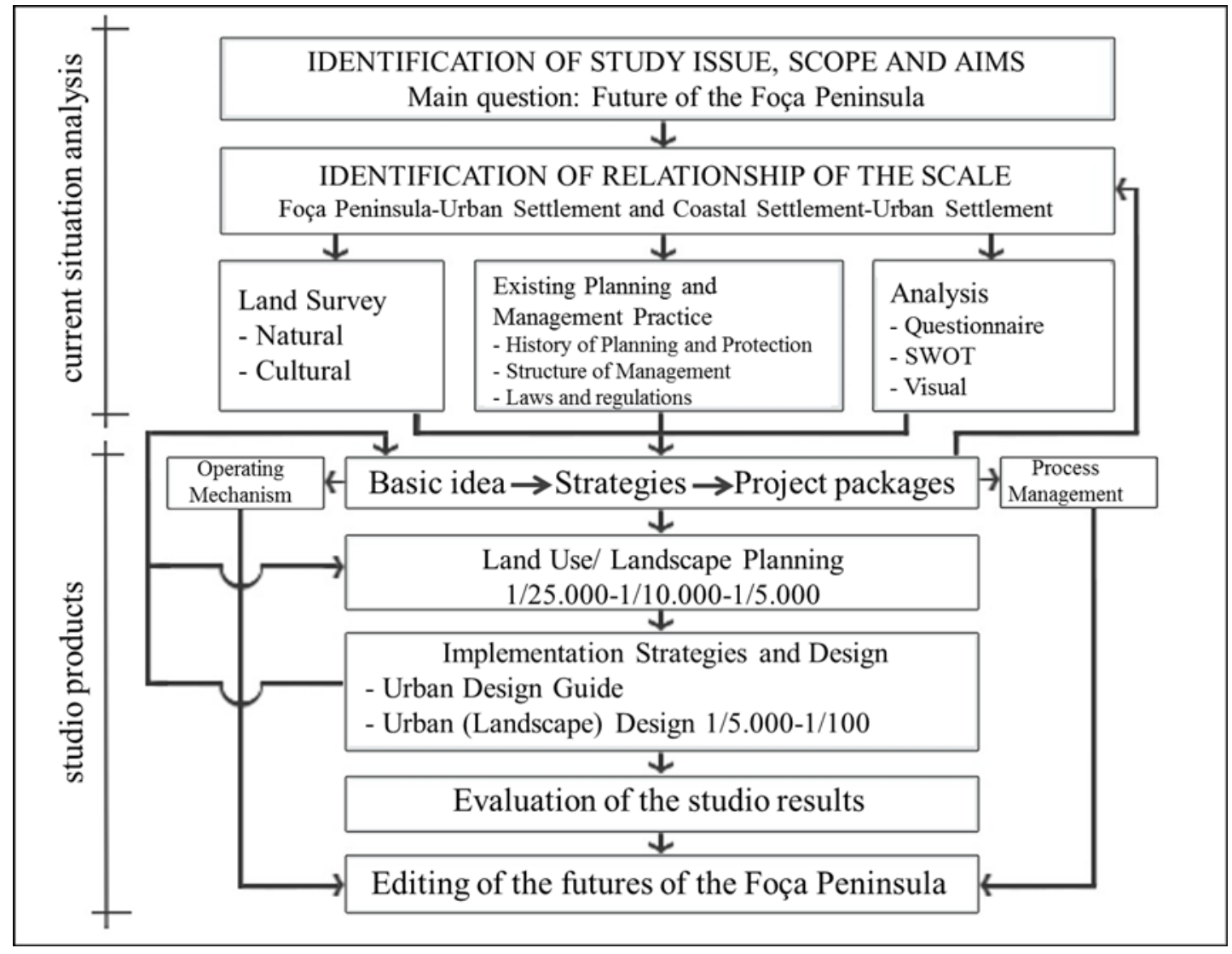

Figure 2. Scheme of work stages. 


\section{Analyses \& Findings}

This section reveals 3 main analyses completed by the students of the planning-design studio:

\subsection{Survey Studies}

Survey studies include a questionnaire with 10 questions, filled by 100 people in 3 different sections of the study area: city center, coastal area, and rural areas of Foca Peninsula. In the questionnaire, people were asked to fill the form by giving 1 point to each option. So, the total points exceed 100 points. The questions in the questionnaire are:

Question 1: What are the primary images of Foca? (Figure 3)

a. Coastlines, bays, and islands -45 points g. Rural settlements and life -6 points

b. Traditional architecture and urban fabric - $26 \quad \mathrm{~h}$. Tourism - 45 points

points

c. Archeological artifacts - 27 points

d. Quiet and clean ambiance -40 points

i. Natural Structure - 32 points

e. Mediterranean monk seal -41 points

j. Fishing - 42 points

k. Agricultural products - 14 points

f. Others (military facilities, cleanness, the lifestyle, vacation, protection, wine grapes \& Foca yoghurt, lent lily plant) -8 points

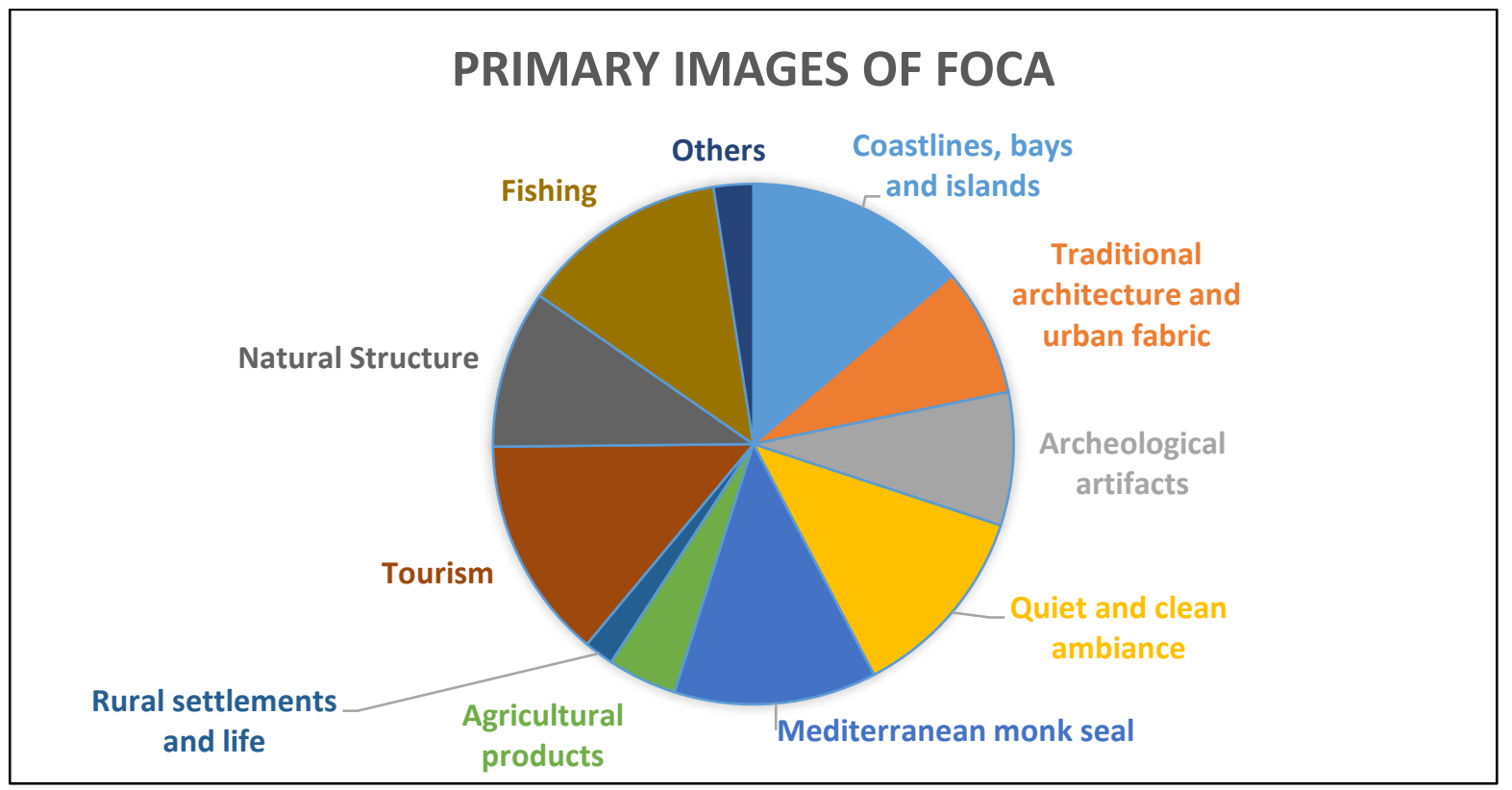

Figure 3. Visual analysis vantage points of the $8^{\text {th }}$ group.

2. Which of the following articles should be given importance for the new activities in Foça center? (by priority)

a. Archeological and urban protection status -113 points

b. Natural protected area status and specially protected environment area status -92 points

c. Preserving the settlement fabric and residential structures from the past -150 points

d. Increasing the tourism, recreation and commercial capacity of Foca. - 134 points

e. Developing agriculture and handicraft activities in and/or outside the city -75 points

f. Developing trade and small industry activities in and/or outside the city -85 points

g. Supporting the fishing industry -123 points

h. Supporting the local bazaar -61 points

i. Enabling the yacht tourism -59 points

j. Residential settlements and summer houses -22 points

$\mathrm{k}$. Allowing the diversification of sea sports -65 points

1. Others -21 points 
3. Which of the following articles should be given importance for the new activities in Foça coastal region (English Cape - Aslanburnu Hill)? (by priority)

a. Natural protected area status and specially protected environment area status -129 Total - 1st: 18 points, 2 nd: 9 points, 3rd: 2 points, 4th: 4 points, 5 th: 1 points.

b. Protecting and reviving the historical architectural structures - 110 Total: 1 st: 16 points, 2nd: 12 points, 3rd: 4 points, 4th: 1 point, 5 th: 3 points, 6 th: 1 point.

c. Increasing the capacity of recreation and coastal tourism (touristic facility and opportunities) - 215 Total: 1 st: 39 points, 2 nd: 14 points, 3rd: 8 points, 4 th: 5 points, 5 th: 2 points, 6 th: 1 point.

d. Residential settlement and summer houses -36 Total: 1 st: 2 points, 2 nd: 5 points, 3rd: 4 points, 4 th: 3 points. e. Allowing the diversification of sea sports - 118 Total: 1st: 5 points, 2 nd: 24 points, 3 rd: 9 points, 4 th: 10 points, 5th: 6 points.

f. Protecting the natural structures and habitats -126 Total: 1st: 8 points, 2 nd: 15 points, 3rd: 19 points, 4 th: 8 points, 5th: 4 points, 6 th: 1 point.

g. Easing the transportation - 98 Total: 1 st: 6 points, 2 nd: 11 points, 3rd: 13 points, 4 th: 7 points, 5 th: 4 points.

h. Giving opportunities for the ecotourism activities at islands - 68 Total: 1st: 3 points, 2nd: 6 points, 3rd: 10 points, 4 th: 8 points, 5 th: 4 points, 6 th: 2 points.

i. Supporting the fishing industry -70 Total: 1 st: 3 points, 2nd: 12 points, 3 rd: 10 points, 4 th: 6 points, 5 th: 5 points, 6th: 4 points.

j. Others (reopening Club Med, increasing the use of fertile soils, cleaning, developing craft activities, opening the French Holiday Resort) - 18 Total: 1st: 1 point, 2nd: 1 point, 3rd: 1 point.

4. Which of the following articles should be given importance in the activities to be carried out at Foça Peninsula?

a. Compliance with the requirements of protection statutes -102 Total.

b. Developing renewable and alternative energy resources -152 Total.

c. Organic farming and diversifying agricultural products -236 Total.

d. Developing the tourism sector of Foca Peninsula- 148 Total.

e. Developing animal husbandry and apiculture sectors - 191 Total.

f. Forestry activities -47 Total.

g. Supporting the local bazaar -67 Total.

h. Enabling the yacht tourism - 51 Total.

i. Increasing the qualifications of rural settlements and life quality -91 Total.

j. Others (converting teacherage to a museum, winery) -6 Total.

5. Indicate the most important 3-5 problems or threats for Foca Peninsula.

Infrastructure: 22 points, military sites: 4 points, destruction of fishing industry and fish: 7 points, environmental pollution: 16 points, destroying the natural and historical structure: 14 points, animal shelters: 5 points, summer houses: 6 points, town planning problems: 8 points, non-supporting the rural development: 5 points, bad management and apathetic citizens: 4 points, museums: 2 points, forest fires: 3 points, auto park, pedestrian and vehicle roads:4 points, lack of social and cultural activities: 8 points, undeveloped agriculture and animal husbandry: 25 points, agriculture: 5 points, thermal power plants and industry: 15 points, commercial promotion: 24 points, lack of tourism activities: 26 points, transportation: 21 points, renewable energy: 1 points.

\section{Indicate the most important 3-5 problems or threats for Foca center.}

Infrastructure: 25 points, environmental pollution: 14 points, lack of tourism development: 13 points, unemployment: 12 points, auto park, pedestrian and vehicle roads: 12 points, protection status: 12 points, lack of social and cultural activities: 11 points, non-protection of natural and historical structures: 10 points, tourism:4 points, transportation: 4 points, bazaar: 3 points, agriculture: 3 points, military areas: 2 points, fishery: 2 points, not helping the street animals: 1 points, lack of the entrance of the city: 1 points, thermic power plant: 1 points.

\section{Indicate the most important 3-5 problems or threats for Foca coastline.}

Deterioration of the natural structure: 40 points, hard transportation: 18 points, insufficient infrastructure: 4 points, harbor for boats: 3 points, military holding the best bays: 8 points, forest fires: 3 points, non-usage of holiday villages: 3 points, no free public beaches: 4 points, unimportance of sea sports: 4 points, lack of accommodation (hotels etc.): 21 points, protection status: 4 points, fishery: 9 points, agriculture: 3 points, unemployment: 4 points, security: 3 points, lack of houses: 3 points. 
8. In which sectors and/or subjects do you see the future of the Foca Peninsula?

Tourism: 72 points, agriculture: 51 points, fishery: 22 points, animal husbandry: 19 points, protection: 11 points, natural and cultural structure (revival of the historical buildings): 10 points, organic farming: 8 points, industry: 5 points, social activities (entertainment and night life): 4 points, sports activities (sea and nature based): 4 points, vinery: 4 points, renewable energy: 4 points, transportation: 3 points, viniculture: 3 points, local bazaar: 2 points, handcrafts: 2 points.

9. In which sectors and/or subjects do you see the future of the Foca center?

Tourism: 70 points, fishery: 33 points, socio-cultural activities: 12 points, agriculture/slowfood bazaar: 11 points, historical heritages: 5 points, handcrafts/local food/local products: 5 points, recreational activities/entertainment sector: 5 points, protection status: 4 points, boat/yacht tourism: 3 points, archeological activities: 3 points, renewable energy: 2 points, animal husbandry: 2 points, commerce: 2 points, water sports: 2 points, business opportunity: 2 points, transportation: 2 points, vinery: 1 points, industry: 1 points, rural development: 1 points, other (municipal services, animal shelters, peaceful and clean ambiance): 3 points.

10. In which sectors and/or subjects do you see the future of the Foca coastline?

Tourism: 75 points, fishery: 35 points, water sports: 28 points, protection: 8 points, boat/yacht tourism: 5 points, Recreational activities/nature sports/activities: 4 points, lodging industry: 3 points (Club Med style), beekeeping: 2 points, history: 1 points, wildlife: 1 points, summer houses: 1 points, others (sea transportation, daily tours to islands of Greece, cleaning the public beaches): 3 points.

\subsection{Visual Analysis}

Within the Visual analyses, 10 groups of students took a total number of 100 photographs across several regions and points. Later, they noted down the positive and negative visual qualifications of the photographs according to vistas. Below, is the visual analysis example from the $2^{\text {nd }}$ photograph prepared by the $8^{\text {th }}$ group (Figure 4 \&5):
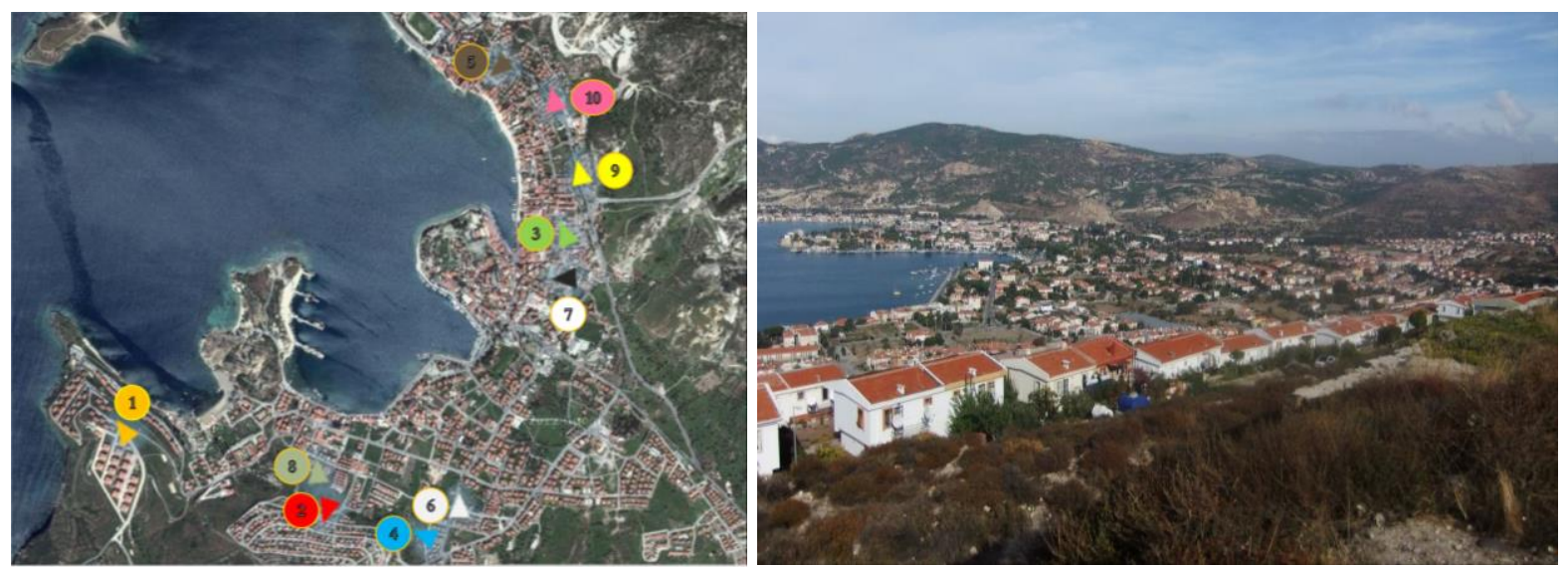

Figure 4 (on the left). Visual analysis vantage points of the $8^{\text {th }}$ group (Google earth, 2012).

Figure 5 (on the right). $2^{\text {nd }}$ photograph of the $8^{\text {th }}$ group.

The positive qualifications of this vista and the point of the qualifications are: naturel structure (3), good scenery (16), urban fabric and silhouette (5), vegetation and green areas (5), observation platform (2), protected natural structure (2).

The negative qualifications of this vista and the point of the qualifications are: residents (23), natural structure of the center is mainly destroyed (7), disordered urban fabric (15). All other visual analyses are characterized as above. This paper does not reveal the complete visual analyses due to page and word restrictions.

\subsection{SWOT Analysis}

The students divided the study area into 10 parts (1- Kucukdeniz, 2- Antique Peninsula, 3- Buyukdeniz, 4- Foca behind the shoreline, 5- Aslanburnu, 6- Islands, 7- Kozbeyli Yenikoy villages, 8- Ilipinar village, 9- Bagaras1, 10- Gerenkoy) to simplify the process of SWOT analysis. Below, is a SWOT analysis example of the antique peninsula section (Figure 6\&7): 


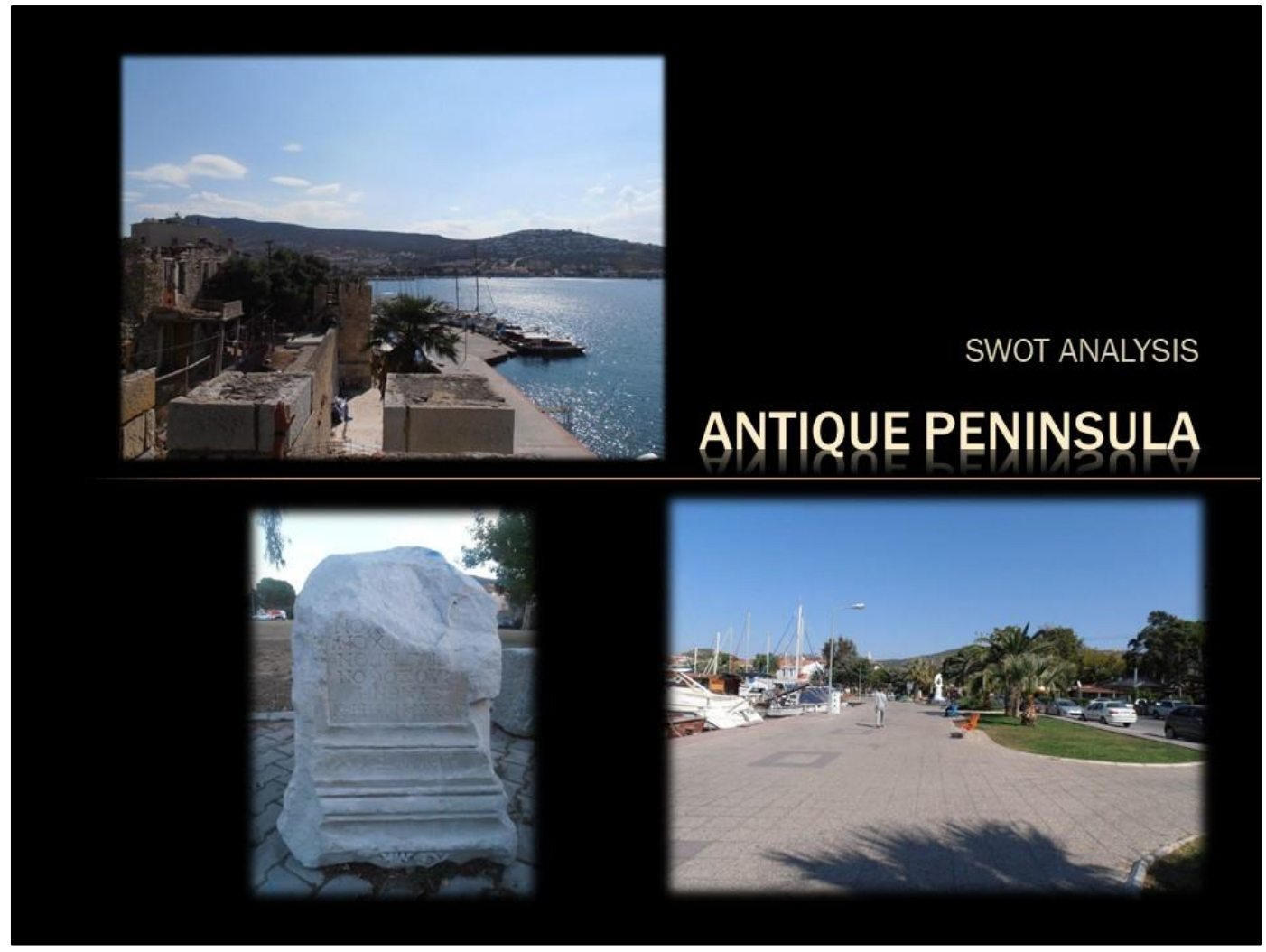

Figure 6. SWOT analysis of the antique peninsula section.

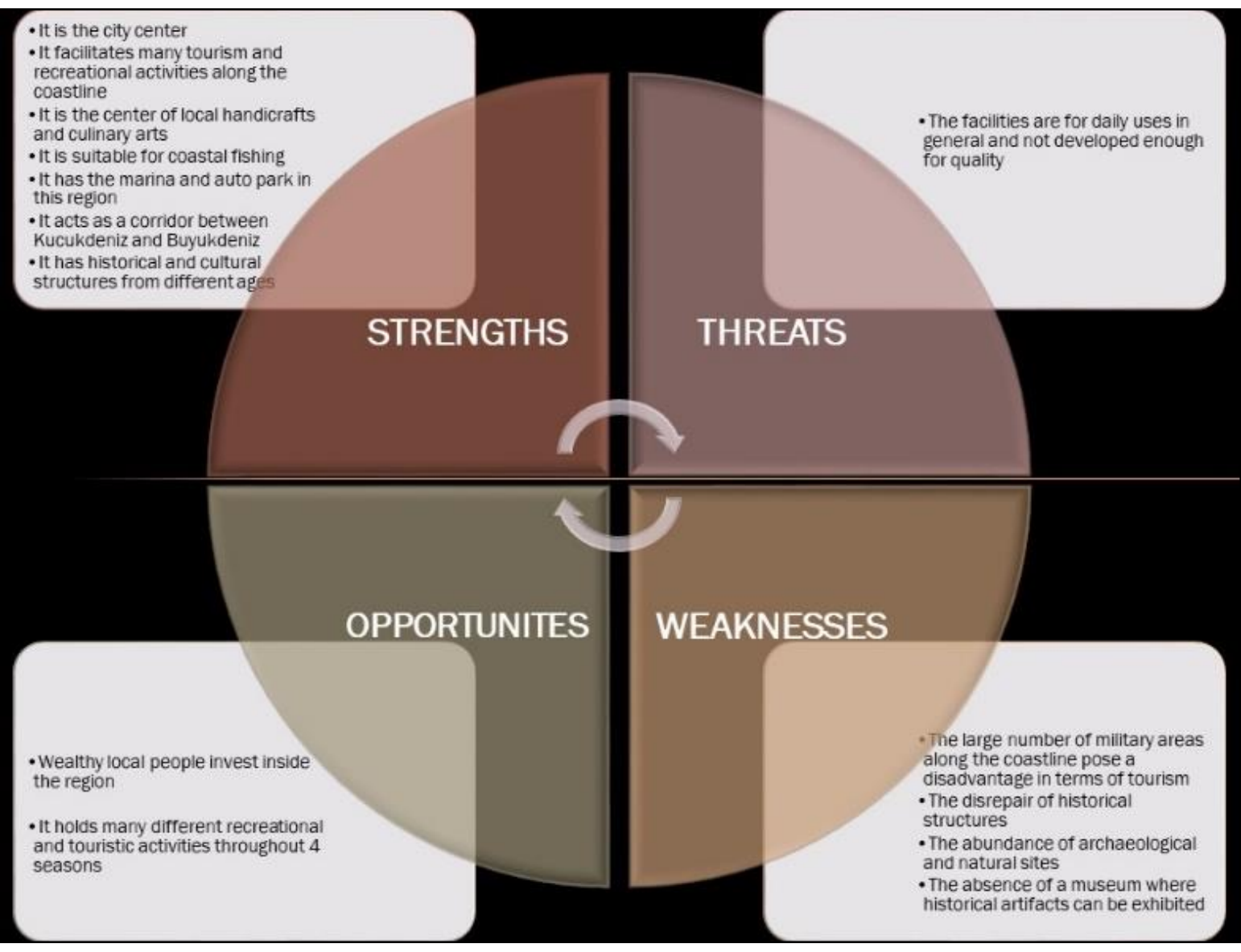

Figure 7. SWOT analysis of the antique peninsula section. 
Strengths: It is the city center, facilitates many tourism and recreational activities along the coastline, the center of local handicrafts and culinary arts, suitable for coastal fishing, the marina and auto park are in this region, it acts as a corridor between Kucukdeniz and Buyukdeniz, it has historical and cultural structures from different ages.

Weaknesses: The large number of military areas along the coastline pose a disadvantage in terms of tourism, the disrepair of historical structures, the abundance of archaeological and natural sites, the absence of a museum where historical artifacts can be exhibited.

Opportunities: Wealthy local people invest inside the region, it holds many different recreational and touristic activities throughout 4 seasons.

Threats: The facilities are for daily uses in general and not developed enough for quality.

All other SWOT analyses are characterized as the example above. After the regional SWOT is completed, all SWOT analyses are gathered into a long list of matters. Lastly, the sectoral SWOT is summarized for 3 sections (urban-coast-peninsula) by considering the natural, and cultural structure, legislations and landscape planning. Below, is a section of the sectoral SWOT analysis (Table 1). This example shows the facts for agriculture sector. Other sectors are, protection, tourism, urban growth, fishery, rural development, transportation. This paper does not reveal the complete SWOT analyses due to page and word restrictions.

It is understood from the analyses that the region loses its natural and cultural heritages over time. It will be useful for the planner to protect and develop them while designing or planning any other activity.

Table 1. A section of the SWOT analysis.

\begin{tabular}{|c|c|c|c|}
\hline SECTORS & CENTER & COASTLINE & PENINSULA \\
\hline \multirow[t]{7}{*}{ AGRICULTURE } & $\begin{array}{l}\text { There is no cultivated } \\
\text { land in the region in } \\
\text { general, and the region } \\
\text { is generally shaped by } \\
\text { residential areas. The } \\
\text { people living behind the } \\
\text { coastal region are more } \\
\text { or less interested in } \\
\text { agriculture and } \\
\text { greenhouse cultivation. }\end{array}$ & $\begin{array}{l}\text { Trees such as fig, } \\
\text { olive and gumwood } \\
\text { grow naturally in the } \\
\text { region. This creates a } \\
\text { small amount of } \\
\text { agricultural } \\
\text { potential. }\end{array}$ & $\begin{array}{l}\text { Agriculture and animal husbandry are carried out } \\
\text { in the villages between the Bagarası, Gerenkoy, } \\
\text { Ilipinar, Kozbeyli-Yenikoy, and Yeni Bag } \\
\text { villages. }\end{array}$ \\
\hline & \multirow{6}{*}{$\begin{array}{l}\text { The increase in touristic } \\
\text { facilities and the } \\
\text { development of } \\
\text { tourism-based trade in } \\
\text { the region have } \\
\text { regressed agricultural } \\
\text { production. }\end{array}$} & & 4800 ha arable lands exist. \\
\hline & & & The agricultural product pattern is rich. \\
\hline & & & There is a shortage of water in many places. \\
\hline & & & $\begin{array}{l}\text { Non-used areas suitable for agriculture have been } \\
\text { greatly reduced ( } 200 \text { ha). }\end{array}$ \\
\hline & & & $\begin{array}{l}\text { The most produced agricultural products in the } \\
\text { field are cotton, corn, spinach, leek, and tomato as } \\
\text { vegetables, olives, peaches, plums, pomegranates } \\
\text { and citrus fruits as fruits. }\end{array}$ \\
\hline & & & $\begin{array}{l}\text { In agricultural areas, the production economy has } \\
\text { fallen far below the processing level. }\end{array}$ \\
\hline
\end{tabular}

\section{Result and Discussions}

Based on the analyses and findings, the main theme of the project of eco-Foca intend;

- To attain a new identity for Foca Peninsula through the efficient evaluation of potentials on the ecological base,

- $\quad$ To provide the development of locals and to meet their needs by forming a holistic model of growth and development between the urban and rural,

- $\quad$ To create peninsula associated with alternative sectors and that keeps the economical processes depending on renewable energy and eco-effective industry. 
Our basic planning decisions aim to keep the protection and development of Foca Peninsula. The decisions are determined in the planning and design processes under the ecological structure. In this content, a system is foreseen which includes generating clean and renewable energy to gain extra finance for the renovation and tourism activities of the urban. Agricultural production facilities and products grows together with the tourism sector; thus the local urban and rural economies revive. This system maintains its cycle within itself. The basic strategies of planning (Figure 7):

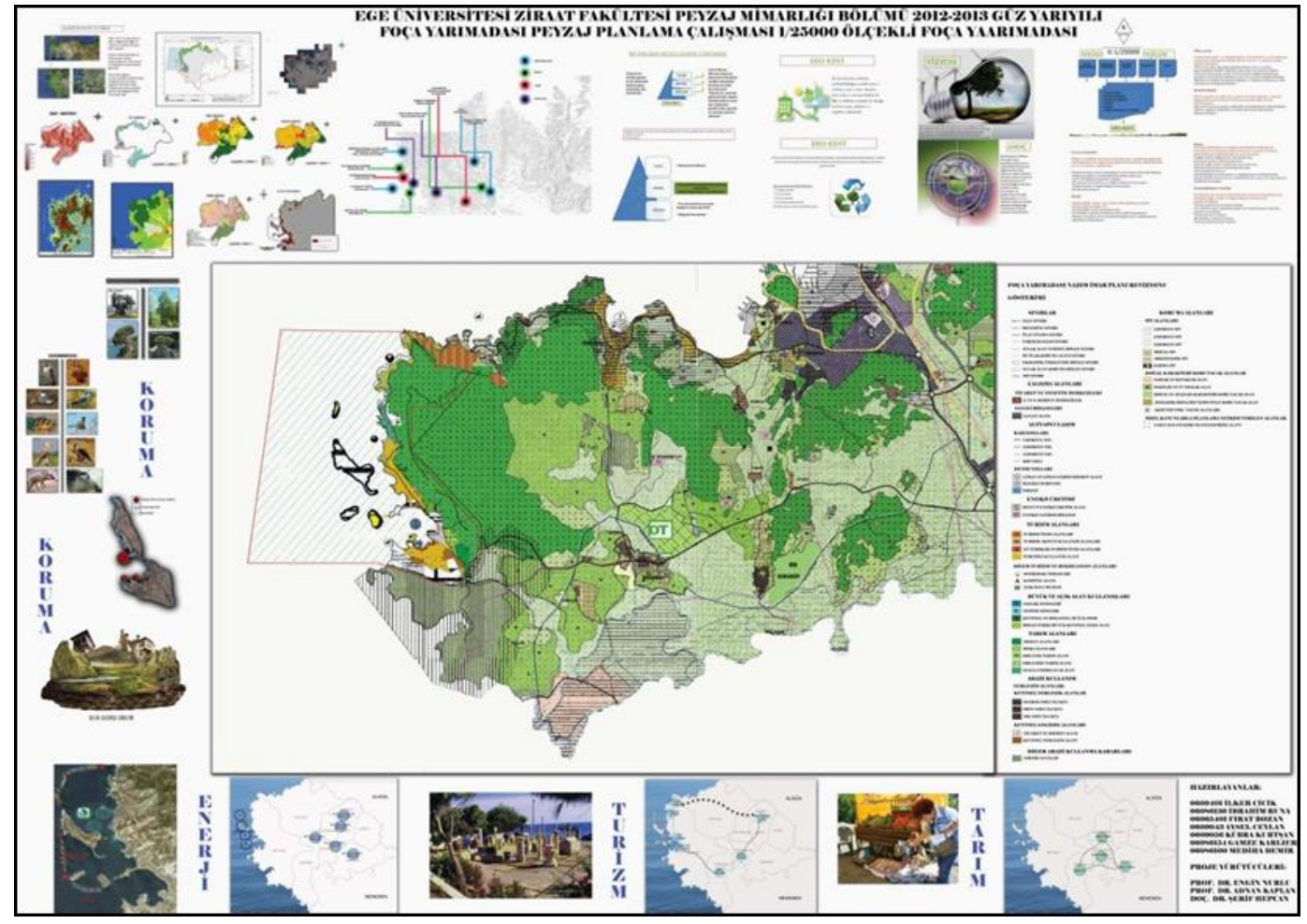

Figure 8. Foça Peninsula landscape planning project (1/25.000).

\section{Nature Conservation}

- $\quad$ Preserving the existing and planned ecological corridors,

- $\quad$ Preserving the water basins, natural areas, coast areas, supporting the attempts to preserve the natural and cultural environment, enabling scientific research in this region,

- $\quad$ Forming the transitive green network among the urban, rural and coast, preserving and extending the natural flora,

- $\quad$ Supporting geotourism by preserving the geological heritage.

\section{Energy}

- Increasing the life quality by developing projects about sustainable ecosystem management and minimization of carbon releasing,

- Creating a self-sufficient urban by extending the usage of renewable energy (wind, sun, and wave energy), converting the islands to energy islands, utilizing the poultry farm wastes as biogas,

- $\quad$ Extending the energy-saving buildings.

\section{Development}

- $\quad$ Ensuring the economic process by developing connection between the urban and rural

- Developing and branding local slow food bazaar of Foca,

- Supporting organic agriculture and animal products and fishing,

- Increasing the processing facilities and attention of the young population,

- Developing rural economy by agro tourism, 


\section{Agriculture}

- Increasing outputs by protecting agricultural areas and restricting structuring,

- $\quad$ Establishing an organization model for agriculture sectors

- Supporting traditional and modern agriculture technics and to diversify the products and marketing.

Historical Urban Identity

- Developing the urban identity with a holistic approach, highlighting traditional fabric by restoring, providing a standardization to the face of the structures,

- Developing tourism by valuing historical buildings as boutique hotels, art galleries, museums, etc. and by this way, increasing the awareness to the identity,

- Working on protecting and introducing the archeological sites,

- Managing the urban sprawl by creating buffer zones, evaluating existing buildings with alternative purposes for economic development, preventing the damage of the urban sprawl.

\section{Tourism}

- Diversifying the tourism throughout Foca Peninsula by introducing the natural and cultural values,

- Reviving the settlements by extending the tourism over the whole year,

- Encouraging eco-camps in natural areas such as Kartdere Valley to raise the awareness by experiencing.

Legal and administrative regulations

- Making necessary binding legal-administrative regulations by reviewing $1 / 25.000$ scaled zoning plans,

- Encouraging the organic agriculture and organizing the producer education,

- Increasing locals' awareness of protection and carrying out supportive and informative educational programs.

The urban (landscape) designs combine point decisions and interventions with the holistic vision and organizations (Figure 8). The urban (landscape) designs are created through;

- Setting up an economical model that organizes the potentials of agriculture and tourism as the principle economic values of the peninsula,

- Actualization of the unused potential lands by relating with their environment as a route of economic development,

- Creating different focus points in the route and relating them with urban (landscape) designs.

The planned urban (landscape) designs in the light of the basic principles are;

- Managing the transportation system, minimizing motor transports, creating bicycle paths, pedestrian paths and parking lots.

- $\quad$ Organizing various activities so extend tourism over the whole year

- Uniting the coast and urban under the green network project,

- Supporting improving practices for vegetation and natural life in the Environmental Protection Areas and the Important Bird Areas,

- Constructing landscape bridges for the transition of wildlife and the continuity of plant compositions,

- Constructing bazaars, processing, and marketing local food to keep the income inside the peninsula,

- $\quad$ Developing line fishing,

- Reinforcing the relation between the coast and background area by the street designs,

- Constructing an outdoor museum for the archeological heritage,

- $\quad$ Encouraging water sports,

- Creating opportunities to observe visual potentials of the peninsula through the bird observation areas, observation decks and observation towers. 

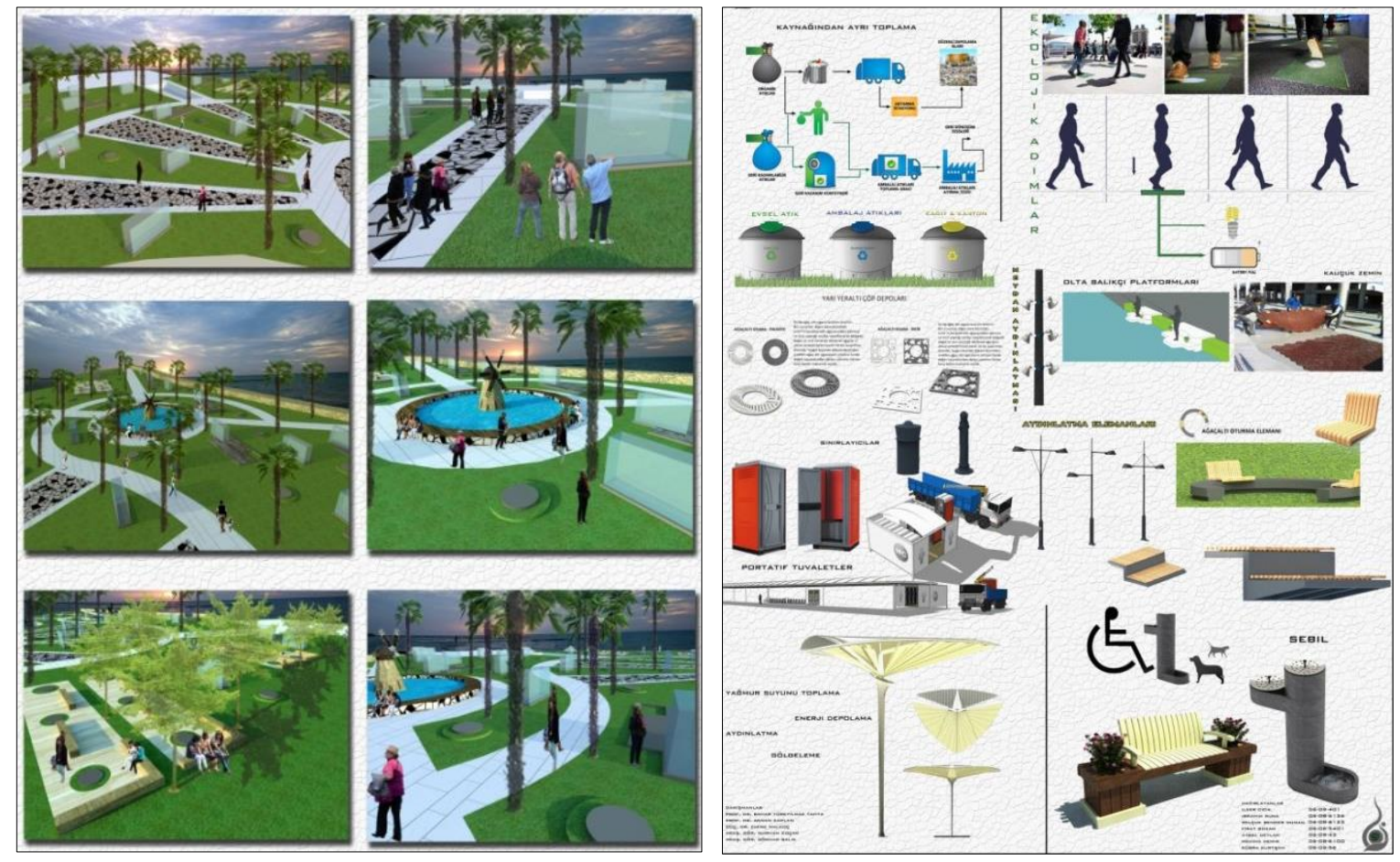

Figure 9. Examples of urban design guide and the outdoor museum design.

\section{Conclusions}

The importance of ecourban has been discussed on Foca Peninsula example together with the problems and possible solutions in the entrance part of the study. The success of ecological concept of natural and cultural settlement depends on all sectors.

Dearborn \& Kark (2010) states that cities with ecologically sensitive urban planning and policies can contribute to the protection of ecological processes and species in urban ecosystems.

Conservation of habitat or ecological connectivity has a key importance for healthy functioning and continuity of ecosystems (Seymour, 2006). Natural or artificial water features are ecologically important in residential areas. Protection or repair of these areas will improve wildlife, vegetation and all the ecological cycle automatically. Also raising awareness of the individuals about ecological approach and eco-urbans are important.

Problems occurred in a local area affect the whole region and especially considering this affect's pressure to the ecology. The ecological approaches become more important in the application of planning, design and management. For this reason, the holistic approaches and solutions are considered as more effective in the planning and design studies. The planning and design problems in Foca Peninsula triggered the study. In this process, the opinions and suggestions are developed supporting the investment of the urban and rural development.

In conclusion, in order to develop Foca Peninsula with a concept like eco-urban or other concepts; a highly comprehensive research should be done for the whole planning/design process.

\section{References}

1. Ankaralı, A. (2008). Foca Yakın Çevresinde Araziden Yararlanma ve Yörede Araziden Yararlanma Bilincinin Değerlendirilmesi. Dissertation Master Thesis. Dokuz Eylül University Graduate School of Natural and Applied Sciences, Geography Teaching Program, İzmir, Turkey.

2. Botequilha Leita, A., Miller, J., Ahern, J. and McGarigal, K. (2006). Measuring Landscapes: a Planners Handbook, Island Press, Washington. 
3. CIN (2012). Cittaslow International Network. Retrieved November 15, 2012, from http://www.cittaslow.org.html.

4. Cetin, A. (2002). Changing Process of the Physical and Social Structures of Eski Foca. Dissertation Master Thesis, İzmir Institute of Technology Department of City and Regional Planning Master of City Planning Program, İzmir, Turkey.

5. Dearborn, D., Kark, S. (2010). Motivations for Conserving Urban Biodiversity, Conservation Biology 24(2): 432-440.

6. Francis, R.A. and Hoggart, S.P. (2009). Urban River Wall Habitat and Vegetation: Observations from the River Thames through Central London, Urban Ecosystems 12:465-485.

7. Google Earth (2012). WorldView-2 Satellite View, accessed: 18.12.2012.

8. İzmir Metropolitan Municipality (2012). 1/25.000 Statement Report of the Environmental Plan (1/25.000) of İzmir Metropolitan Area. The Department of City Planning of İzmir Metropolitan Municipality, İzmir, Turkey.

9. Kaboğlu, G. (2007). Implementation of Protection of Endangered Species and Their Habitats to the Integrated Coastal Zone Management Concept: A Case Study for the Mediterranean Monk Seal (Monachus monachus) in Foca, İzmir. Dissertation Master's Thesis, Dokuz Eylül University Graduate School of Natural and Applied Sciences Master of Science in the Institute of Marine Sciences and Technology, Coastal Zone Management Program, İzmir.

10. Kaplan, A. (1995). Doğal ve Kültürel Değerlerce Zengin Kıyı Mekanlarına Yönelik Peyzaj Planlama Yönteminin Foca Örneğinde Ortaya Konulması Üzerinde Araştırmalar. Dissertation PhD Thesis, Ege University Institute of Natural and Applied Sciences, Landscape Architecture Department, İzmir, Turkey.

11. RMIT (2008). RMIT University School of Architecture and Design. Live Projects: Locating Models of Community-engaged Design Studios in University Education Symposium. 15-16 October 2008, Melbourne.

12.Seymour, M., Byrne, J., Martino, D. and Wolch, J. (2006). Green Visions Plan for 21st Century Southern California: A Guide for Habitat Conservation, Watershed Health and Recreational Open Space. 9. Recreationist-Wildlife Interactions in Urban Parks, University of Southern California GIS Research Laboratory and Center for Sustainable Cities, Los Angeles, California.

13. Soulé, M.E. (1991). Land Use Planning and Wildlife Maintenance: Guidelines for Conserving Wildlife in an Urban Landscape, Journal of the American Planning Assoc. 57(3):313-323.

14. Urban Ecology Australia (2013). Urban Ecology Australia. Retrieved July 20, 2013, from http://www.urbanecology.org.au. 